FEATURE

Peter Evans, Michael Hatcher

and Damian Whittard

Office for National Statistics

\title{
The preliminary R\&D satellite account for the UK: a sensitivity analysis
}

\section{SUMMARY}

This article builds on previous work in Economic \& Labour Market Review which treated expenditure on research and development as investment in an intangible scientific asset, in line with proposed revisions to the System of National Accounts (SNA). The purpose of the analysis is to communicate to users the degree of sensitivity of the results previously presented to changes in the key assumptions. The analysis is part of a wider Office for National Statistics contribution to Organisation for Economic Co-operation and Development work updating the 1993 SNA, and was presented at the International Association for Research on Income and Wealth conference in Slovenia in August 2008.
( ne of the major recommended changes to the 1993 System of National Accounts (1993 SNA) is that research and development $(\mathrm{R} \& \mathrm{D})$ expenditure should be treated as investment in an intangible scientific asset, with its definition following the Organisation for Economic Co-operation and Development's Frascati Manual (OECD 2002). As a precursor to incorporation into countries' national accounts, the recommended changes are to be documented in experimental R\&D satellite accounts. While the revision timetable spans a number of years, many statistical agencies, including the Office for National Statistics, have already conducted preliminary assessments to communicate the potential impacts to users.

In a previous issue of Economic \& Labour Market Review, Galindo-Rueda (2007) presented preliminary analysis for the UK treating R\&D as a capital asset. Capitalising R\&D would raise UK gross domestic product (GDP) by approximately 1.5 per cent, have non-trivial impacts on $\mathrm{R} \& \mathrm{D}$ intensity indicators and key economic ratios, but limited effect on estimates of recent GDP growth. The treatment of R\&D as a capital asset also has impacts on the goods and services account (GSA).

In this article, a sensitivity analysis on Galindo-Rueda's preliminary results is carried out. The areas investigated are: the GSA impacts, GDP and net domestic product (NDP) estimates, R\&D intensity indicators, key economic ratios and growthaccounting results. The focus of the analysis is the assumptions made with respect to depreciation rates for R\&D and fixed assets, the inclusion of software, and the funding and ownership assumptions regarding $\mathrm{R} \& \mathrm{D}$ across various sectors. ${ }^{1}$ The aim of the article is to communicate to users the degree of sensitivity of the results previously presented to changes in the key assumptions.

\section{The key assumptions}

Depreciation rates

\section{R\&D stocks}

Treating $R \& D$ as an asset requires a number of assumptions, one of the most important of which is the rate of depreciation. Using a constant price series for R\&D gross fixed capital formation (GFCF), end-ofperiod R\&D stocks were calculated using a perpetual inventory model (PIM), which adds new investment to capital stock, and subtracts depreciation. In the original benchmark analysis by Galindo-Rueda (2007), a depreciation rate of 20 per cent was applied to the business sector's R\&D stock, while a 5 per cent rate was applied to the government and non-profit institutions serving households (NPISH) sectors.

The 20 per cent business sector rate is consistent with a ten-year service life under a double-declining balance rate, and close to the 24 per cent estimated for the UK by Schankerman and Pakes (1986) using patent renewal methods. In the empirical literature, it has been estimated that business sector R\&D capital depreciates at two to seven times the rate of physical capital, with estimates ranging from 10 to 25 per cent depending on the sector considered (Edworthy and Wallis 2007). The government and NPISH depreciation rates of 5 per cent are outside this range, 
reflecting the likelihood of slower depreciation of knowledge produced for more general applications.

A comparison of depreciation rates used in international $\mathrm{R} \& \mathrm{D}$ satellite accounts is given in Table $1 .^{2}$ On the basis of these rates and estimates in the literature, three scenarios for the business sector are considered: 15 per cent, 20 per cent (original) and 25 per cent, ${ }^{3}$ and three scenarios for the government and NPISH sectors: 2.5 per cent per cent, 5 per cent (original) and 7.5 per cent.It is assumed that the same depreciation rate always applies in the government and NPISH sectors.

\section{Fixed assets stocks}

In the benchmark analysis, stocks of fixed assets used for R\&D for the two separate categories in the Business Enterprise Research and Development survey (land and buildings and plant, machinery and equipment) depreciate geometrically according to the PIM, with capital services for the use of both stocks calculated assuming a net rate of return (ROR) of 7 per cent. A 1.5 per cent depreciation rate was applied to land and buildings, and 15 per cent for machinery and equipment.

These rates are consistent with the finding that physical capital depreciates more slowly than business sector R\&D capital, though the latter is only slightly below the business sector's R\&D capital depreciation rate of 20 per cent. In this analysis, three scenarios are considered: 0.5 per cent, 1.5 per cent (original) and 2.5 per cent for land and buildings, and 10 per cent, 15 per cent (original) and 20 per cent for plant, machinery and equipment. The net ROR of 7 per cent is applied in each case.

\section{Software estimates}

To avoid double counting of software, which is currently recognised as a produced asset in the National Accounts (NA), and scientific originals (R\&D) which are not, 50 per cent of total R\&D in the computer services industry was deducted in the benchmark analysis (it is assumed this proportion is already correctly accounted for in software estimates). In addition, 60 and 40 per cent deductions are considered.

\section{Performance, funding and ownership of R\&D}

In the benchmark analysis, a number of assumptions are made about the share of each sector's R\&D that is funded and owned by another sector. The sensitivity to changes in some of these assumed shares is also investigated, again using three scenarios. The assumptions used in the sensitivity analysis are presented in Table 2, with the original assumptions labelled.

Table 1

\section{Comparison of service lives and depreciation rates in international R\&D satellite accounts}

\begin{tabular}{llll}
\hline Country & Average service life (years) & Annual depreciation rate (\%) & Comments \\
\hline Australia & 5,10 and 20 & NA & Three scenarios \\
Canada & NA & 5,10 and 15 & Three scenarios \\
Israel & NA & 15 & None \\
Netherlands & 9.5 to 15.5 & NA & Vary across industry groups \\
UK & NA & 20 (business) & None \\
US & NA & 5 (government and NPISH) & \\
& & $11-18$ (business) & Vary across four industry groups \\
\end{tabular}

Source: OECD (2008)

Table 2

\section{Funding-ownership assumptions in the sensitivity analysis}

\begin{tabular}{|c|c|c|c|c|c|c|c|c|}
\hline \multirow[b]{2}{*}{ Funder (i) } & \multicolumn{8}{|c|}{ Share of sector i's R\&D funded by sector $\mathrm{j}$ that is owned by sector $\mathrm{j}$} \\
\hline & $\begin{array}{r}\text { Business } \\
\text { enterprise }\end{array}$ & \multicolumn{3}{|c|}{ General government } & NPISH & \multicolumn{3}{|c|}{ Rest of World } \\
\hline Performer (j) & Original & & iginal & & Original & & iginal & \\
\hline $\begin{array}{l}\text { Business } \\
\text { enterprise }\end{array}$ & 1.00 & 0.40 & 0.50 & 0.60 & 1.00 & 0.85 & 0.90 & 0.95 \\
\hline $\begin{array}{l}\text { General } \\
\text { government }\end{array}$ & 1.00 & 1.00 & 1.00 & 1.00 & 1.00 & 0.85 & 0.90 & 0.95 \\
\hline NPISH & 1.00 & 0.05 & 0.10 & 0.15 & 1.00 & 0.85 & 0.90 & 0.95 \\
\hline Rest of World & 0.90 & 1.00 & 1.00 & 1.00 & 0.76 & 0.22 & 0.22 & 0.22 \\
\hline
\end{tabular}

\section{Results}

\section{Impacts on the goods and services account}

The goods and services account (GSA) balances total resources (supply), from output and imports, against possible uses (demand). Like Galindo-Rueda, concentration is on the impacts of $R \& D$ capitalisation. The figures presented therefore reflect the changes relative to NA values for the 2004 reference year. The sensitivity with respect to depreciation rates is considered first.

\section{Depreciation rates}

NPISH and government R\&D capital

The changes, which are documented in

Table 3, are non-trivial. The impact on total demand rises by approximately 19 per cent if the depreciation rate is increased from the original 5 per cent value to 7.5 per cent. However, this does result only from increases in final consumption of services from $R \& D$ capital by the NPISH and government sectors, which increase by 65 and 12 per cent, respectively. Reducing the depreciation rate from 5 to 2.5 per cent reduces total demand through the same channels but, interestingly, the effect is less marked. Thus, while the total demand impact shows significant sensitivity to even small changes in these depreciation rates, it is more sensitive to an increase from the benchmark value.

\section{Business R\&D capital}

Changing the business R\&D capital depreciation rate has no effect on the GSA. This result follows from the elimination of the channels discussed above via the imposed constraint, used to estimate adjustments to other goods and services on the supply and use sides, that non-market gross value added (GVA) increases only by the value of R\&D capital consumption in the government and NPISH sectors.

\section{Land and buildings}

Changing the depreciation rate leads to changes in almost all the components of total demand, but the overall impact is small. Increasing the rate from the original value of 1.5 per cent to 2.5 per cent reduces total demand impact by 1.3 per cent, resulting mainly from a reduction in the capitalisation of $R \& D$ investment (that is, R\&D GFCF) from $£ 19.407$ billion to $£ 19.213$ billion. For such a small change in the depreciation rate, this is certainly non-trivial, but reducing the depreciation rate by 1 percentage point to 0.5 per cent produces an even greater effect. The total demand 
Table 3

\section{Sensitivity of GSA impacts to NPISH and government R\&D capital depreciation rates, 2004}

f million, current prices

\begin{tabular}{|c|c|c|c|}
\hline \multicolumn{4}{|l|}{ Resources } \\
\hline Depreciation rate & $2.5 \%$ & $5 \%$ (original) & $7.5 \%$ \\
\hline$R \& D$ output & Unchanged & 12,403 & Unchanged \\
\hline Output of other goods and services (OGS) & Unchanged & $-9,089$ & Unchanged \\
\hline $\begin{array}{l}\text { Output of OGS from other non-market consumption } \\
\text { of R\&D capital services }\end{array}$ & 3,219 & 4,216 & 5,671 \\
\hline$R \& D$ imports & Unchanged & 197 & Unchanged \\
\hline Total supply of R\&D & Unchanged & 12,600 & Unchanged \\
\hline Total supply of OGS & $-5,870$ & $-4,873$ & $-3,418$ \\
\hline Total supply & 6,730 & 7,727 & 9,182 \\
\hline \multicolumn{4}{|l|}{ Uses } \\
\hline$R \& D$ intermediate consumption & Unchanged & $-5,274$ & Unchanged \\
\hline Intermediate consumption OGS & Unchanged & $-1,363$ & Unchanged \\
\hline$R \& D$ gross fixed capital formation & Unchanged & 19,407 & Unchanged \\
\hline Gross fixed capital formation other assets & Unchanged & 0 & Unchanged \\
\hline Changes in inventories & Unchanged & 12 & Unchanged \\
\hline Final consumption of R\&D by NPISH & Unchanged & -325 & Unchanged \\
\hline Final consumption of OGS by NPISH & Unchanged & $-5,084$ & Unchanged \\
\hline $\begin{array}{l}\text { Final consumption of services from R\&D capital by } \\
\text { NPISH }\end{array}$ & 1,124 & 1,776 & 2,939 \\
\hline Final consumption of OGS by government & Unchanged & $-2,641$ & Unchanged \\
\hline $\begin{array}{l}\text { Final consumption of services from R\&D capital by } \\
\text { government }\end{array}$ & 2,095 & 2,440 & 2,732 \\
\hline$R \& D$ exports & Unchanged & $-1,219$ & Unchanged \\
\hline Total demand of R\&D & Unchanged & 12,600 & Unchanged \\
\hline Total demand of OGS & $-5,870$ & $-4,873$ & $-3,418$ \\
\hline Total demand & 6,730 & 7,727 & 9,182 \\
\hline
\end{tabular}

Source: Office for National Statistics

Table 4

Sensitivity of GSA impacts to the land and buildings depreciation rate, 2004

f million, current prices

\begin{tabular}{|c|c|c|c|}
\hline \multicolumn{4}{|l|}{ Resources } \\
\hline Depreciation rate & $0.5 \%$ & $1.5 \%$ (original) & $2.5 \%$ \\
\hline$R \& D$ output & 12,988 & 12,403 & 12,151 \\
\hline Output of other goods and services (OGS) & $-9,006$ & $-9,089$ & $-9,124$ \\
\hline $\begin{array}{l}\text { Output of OGS from other non-market consumption } \\
\text { of R\&D capital services }\end{array}$ & 3,828 & 4,216 & 4,402 \\
\hline$R \& D$ imports & Unchanged & 197 & Unchanged \\
\hline Total supply of R\&D & 13,185 & 12,600 & 12,348 \\
\hline Total supply of OGS & $-5,178$ & $-4,873$ & $-4,722$ \\
\hline Total supply & 8,007 & 7,727 & 7,627 \\
\hline \multicolumn{4}{|l|}{ Uses } \\
\hline$R \& D$ intermediate consumption & $-5,272$ & $-5,274$ & $-5,275$ \\
\hline Intermediate consumption OGS & $-1,351$ & $-1,363$ & $-1,369$ \\
\hline$R \& D$ gross fixed capital formation & 19,856 & 19,407 & 19,213 \\
\hline Gross fixed capital formation other assets & 0 & 0 & 0 \\
\hline Changes in inventories & Unchanged & 12 & Unchanged \\
\hline Final consumption of R\&D by NPISH & Unchanged & -325 & Unchanged \\
\hline Final consumption of OGS by NPISH & $-5,034$ & $-5,084$ & $-5,105$ \\
\hline $\begin{array}{l}\text { Final consumption of services from R\&D capital by } \\
\text { NPISH }\end{array}$ & 1,612 & 1,776 & 1,854 \\
\hline Final consumption of OGS by government & $-2,621$ & $-2,641$ & $-2,650$ \\
\hline $\begin{array}{l}\text { Final consumption of services from R\&D capital by } \\
\text { government }\end{array}$ & 2,216 & 2,440 & 2,548 \\
\hline$R \& D$ exports & $-1,086$ & $-1,219$ & $-1,277$ \\
\hline Total demand of R\&D & 13,185 & 12,600 & 12,348 \\
\hline Total demand of OGS & $-5,178$ & $-4,873$ & $-4,722$ \\
\hline Total demand & 8,007 & 7,727 & 7,627 \\
\hline
\end{tabular}

Source: Office for National Statistics impact increases by almost 4 per cent, again resulting mainly from the effect on R\&D investment (see Table 4).

Plant, machinery and equipment The total demand impacts of increasing or reducing the depreciation rate are insignificant at less than 1 per cent. Inspection of Table $\mathbf{5}$ shows that this does not result from offsetting elements within demand, but rather because the effects on all elements are quite small. These results stand in contrast to the changes produced by altering the land and buildings depreciation rate.

\section{Software estimates}

Table 6 shows that the total demand impacts of the software deduction assumption are not particularly large. As expected, increasing (decreasing) the percentage deduction of $R \& D$ in the computer services industry decreases (increases) the impact of R\&D capitalisation on total demand, primarily through its effect on R\&D investment. Changing the software deduction by 10 percentage points leads to approximately a 1.6 per cent change in the total demand impact and around a 0.5 per cent change in $\mathrm{R} \& \mathrm{D}$ investment. ${ }^{4}$

Performance, funding and ownership of R\&D

The changes in the GSA impacts differ depending on the funding share considered, but the general result is that there are only small changes in total demand and its individual components. The greatest sensitivity is with respect to the share of governmentfunded and -owned R\&D performed by business enterprise, with changes in the GSA shown in Table 7. The total demand impact changes by 1.25 per cent.

\section{GDP and NDP estimates}

The capitalised estimates as well as their percentage changes relative to the benchmark estimates of Galindo-Rueda (2007) are given in next three tables. The satellite account GDP and NDP estimates refer to all sectors. Table 8 refers to depreciation rates, Table 9 to the software deduction and Table $\mathbf{1 0}$ to the assumed funding-ownership shares.

\section{Depreciation rates} NPISH and government R\&D capital There is no change in the NDP estimate from changing the depreciation rates from the benchmark of 5 per cent. However, there are changes to GDP estimates because, for the government and NPISH sectors, 
Table 5

\section{Sensitivity of GSA impacts to the plant, machinery and equipment depreciation rate, 2004}

f million, current prices

\begin{tabular}{|c|c|c|c|}
\hline \multicolumn{4}{|l|}{ Resources } \\
\hline Depreciation rate & $10 \%$ & $15 \%$ (original) & $20 \%$ \\
\hline R\&D output & Unchanged & 12,403 & Unchanged \\
\hline Output of other goods and services (OGS) & $-9,034$ & $-9,089$ & $-9,122$ \\
\hline $\begin{array}{l}\text { Output of OGS from other non-market consumption } \\
\text { of R\&D capital services }\end{array}$ & 4,204 & 4,216 & 4,225 \\
\hline$R \& D$ imports & Unchanged & 197 & Unchanged \\
\hline Total supply of R\&D & Unchanged & 12,600 & Unchanged \\
\hline Total supply of OGS & $-4,830$ & $-4,873$ & $-4,897$ \\
\hline Total supply & 7,770 & 7,727 & 7,703 \\
\hline \multicolumn{4}{|l|}{ Uses } \\
\hline R\&D intermediate consumption & Unchanged & $-5,274$ & Unchanged \\
\hline Intermediate consumption OGS & $-1,355$ & $-1,363$ & $-1,368$ \\
\hline$R \& D$ gross fixed capital formation & 19,400 & 19,407 & 19411 \\
\hline Gross fixed capital formation other assets & Unchanged & 0 & Unchanged \\
\hline Changes in inventories & Unchanged & 12 & Unchanged \\
\hline Final consumption of R\&D by NPISH & Unchanged & -325 & Unchanged \\
\hline Final consumption of OGS by NPISH & $-5,051$ & $-5,084$ & $-5,104$ \\
\hline $\begin{array}{l}\text { Final consumption of services from R\&D capital by } \\
\text { NPISH }\end{array}$ & 1,768 & 1,776 & 1,781 \\
\hline Final consumption of OGS by government & $-2,628$ & $-2,641$ & $-2,650$ \\
\hline $\begin{array}{l}\text { Final consumption of services from R\&D capital by } \\
\text { government }\end{array}$ & 2,435 & 2,440 & 2,444 \\
\hline$R \& D$ exports & $-1,212$ & $-1,219$ & $-1,224$ \\
\hline Total demand of $R \& D$ & Unchanged & 12,600 & Unchanged \\
\hline Total demand of OGS & $-4,830$ & $-4,873$ & $-4,897$ \\
\hline Total demand & 7,770 & 7,727 & 7,703 \\
\hline
\end{tabular}

Source: Office for National Statistics

\section{Table 6}

\section{Sensitivity of GSA impacts to the software estimates deduction, 2004}

f million, current prices

Resources
Software deduction
$R \& D$ output
Output of other goods and services (OGS)
Output of OGS from other non-market consumption
of R\&D capital services
$R \& D$ imports
Total supply of R\&D
Total supply of OGS

Total supply

Uses

$R \& D$ intermediate consumption

Intermediate consumption OGS

$R \& D$ gross fixed capital formation

Gross fixed capital formation other assets

Changes in inventories

Final consumption of R\&D by NPISH

Final consumption of OGS by NPISH

Final consumption of services from R\&D capital by

NPISH

Final consumption of OGS by government

Final consumption of services from R\&D capital by

government

$R \& D$ exports

Total demand of R\&D

Total demand of OGS

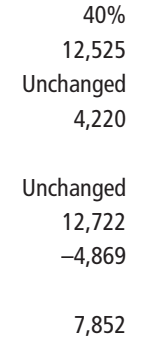

$50 \%$ (original)

12,403

4,216

197

12,600

$-4,873$

7,727

$\begin{array}{rrr}\text { Unchanged } & -5,274 & \text { Unchanged } \\ \text { Unchanged } & -1,363 & \text { Unchanged } \\ 19,503 & 19,407 & 19,311 \\ \text { Unchanged } & 0 & \text { Unchanged } \\ \text { Unchanged } & 12 & \text { Unchanged } \\ \text { Unchanged } & -325 & \text { Unchanged } \\ \text { Unchanged } & -5,084 & \text { Unchanged } \\ \text { Unchanged } & 1,776 & \text { Unchanged } \\ & & \\ \text { Unchanged } & -2,641 & \text { Unchanged } \\ 2,444 & 2,440 & 2,437 \\ & & \\ -1,194 & -1,219 & -1,245 \\ 12,722 & 12,600 & 12,478 \\ -4,869 & -4,873 & -4,876 \\ & & 7,602 \\ 7,852 & 7,727 & \end{array}$

Source: Office for National Statistics the amount of consumption of fixed capital attributable to R\&D is added to both income and expenditure, thereby increasing factor incomes, final expenditure and value added in these sectors. With a 7.5 per cent depreciation rate, GDP increases by 0.05 per cent relative to the preliminary case. If the depreciation rate is reduced to 2.5 per cent instead, the GDP estimate falls by almost one-tenth of a percentage point. GDP estimates are therefore also rather insensitive to the NPISH and government R\&D capital depreciation rates.

Business sector R\&D capital

In this case, it is the NDP estimates that change while the GDP estimates stay constant. The reason for this result is that the consumption of fixed capital that occurs with the depreciation of R\&D assets used in a production process is a portion of total operating surplus. Thus, when business capital is depreciated, the depreciation rate used affects the composition between capital consumption and net operating surplus (and thus NDP), but does not affect GDP. The changes in NDP are rather insignificant: if the depreciation rate is reduced by 5 percentage points to 15 per cent, then there is 0.01 per cent increase in NDP, while an increase up to 25 per cent reduces NDP by 0.02 per cent.

Land and buildings

Both NDP and GDP estimates change relative to the benchmark analysis. Increasing the depreciation rate from 1.5 per cent to 2.5 per cent reduces NDP by 0.1 per cent compared with only a 0.01 per cent reduction in GDP. The corresponding changes for a 1 percentage point reduction in the depreciation rate to 0.5 per cent are similar quantitatively, with the proviso that the directions of change are reversed. Thus, while NDP estimates are more variable than GDP estimates, both sets are rather robust.

Plant, machinery and equipment Both GDP and NDP estimates show little variability to the assumed depreciation rate for plant, machinery and equipment. The changes for GDP and NDP are the same in percentage terms, but an increase in the depreciation rate reduces GDP and increases NDP (and vice versa for a decrease in the depreciation rate). Changes in the plant, machinery and equipment depreciation rate also had only minor impacts on the goods and services account, despite the relatively wide range of values considered.

\section{Software estimates}

A 10 percentage point change in the original software deduction figure of 50 
Table 7

\section{Sensitivity of GSA impacts to the share of government-funded R\&D performed by business enterprise and owned by government, 2004}

\begin{tabular}{|c|c|c|c|}
\hline \multicolumn{4}{|c|}{ f million, current prices } \\
\hline \multicolumn{4}{|l|}{ Resources } \\
\hline Funding share & $40 \%$ & $50 \%$ (original) & $60 \%$ \\
\hline R\&D output & 12,399 & 12,403 & 12,406 \\
\hline Output of other goods and services (OGS) & Unchanged & $-9,089$ & Unchanged \\
\hline $\begin{array}{l}\text { Output of OGS from other non-market consumption } \\
\text { of R\&D capital services }\end{array}$ & 4,123 & 4,216 & 4,309 \\
\hline$R \& D$ imports & Unchanged & 197 & Unchanged \\
\hline Total supply of R\&D & 12,597 & 12,600 & 12,603 \\
\hline Total supply of OGS & $-4,966$ & $-4,873$ & $-4,966$ \\
\hline Total supply & 7,631 & 7,727 & 7,824 \\
\hline \multicolumn{4}{|l|}{ Uses } \\
\hline$R \& D$ intermediate consumption & $-5,278$ & $-5,274$ & $-5,271$ \\
\hline Intermediate consumption OGS & Unchanged & $-1,363$ & Unchanged \\
\hline$R \& D$ gross fixed capital formation & Unchanged & 19,407 & Unchanged \\
\hline Gross fixed capital formation other assets & Unchanged & 0 & Unchanged \\
\hline Changes in inventories & Unchanged & 12 & Unchanged \\
\hline Final consumption of R\&D by NPISH & Unchanged & -325 & Unchanged \\
\hline Final consumption of OGS by NPISH & Unchanged & $-5,084$ & Unchanged \\
\hline $\begin{array}{l}\text { Final consumption of services from R\&D capital by } \\
\text { NPISH }\end{array}$ & Unchanged & 1,776 & Unchanged \\
\hline Final consumption of OGS by government & Unchanged & $-2,641$ & Unchanged \\
\hline $\begin{array}{l}\text { Final consumption of services from R\&D capital by } \\
\text { government }\end{array}$ & 2,347 & 2,440 & 2,533 \\
\hline$R \& D$ exports & Unchanged & $-1,219$ & Unchanged \\
\hline Total demand of R\&D & 12,597 & 12,600 & 12,603 \\
\hline Total demand of OGS & $-4,966$ & $-4,873$ & $-4,780$ \\
\hline Total demand & 7,631 & 7,727 & 7,824 \\
\hline
\end{tabular}

Table 8

\section{Sensitivity of GDP and NDP estimates to depreciation rates, 2004}

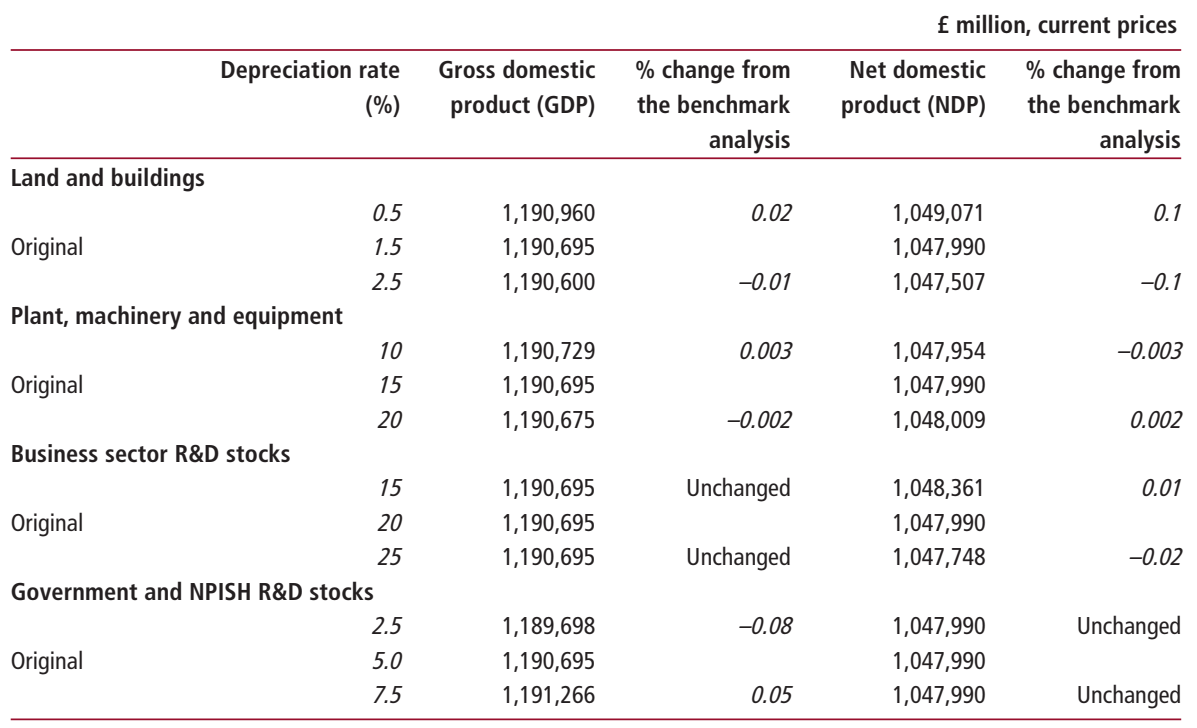

Source: Office for National Statistics

per cent causes a change in GDP of only 0.01 per cent. As expected, increasing the software deduction reduces GDP (as it reduces the potential for double-counting), while a reduction in the software deduction increases GDP. NDP changes in the same direction and by equal magnitude in percentage terms (see Table 9).
40 per cent and fall by 0.01 per cent if the share is increased to 60 per cent. The results for each share are presented in Table 10.

\section{Sensitivity of R\&D intensity indicators and key economic ratios}

Sensitivity with respect to two indicators of R\&D intensity is considered - the GERD/ GDP ratio and R\&D GFCF/GDP - and two key economic ratios - the gross operating surplus (GOS) to GDP ratio and the gross saving to gross national disposable income ratio.

\section{Depreciation rates}

The GERD/GDP ratio, the headline R\&D intensity indicator, does not change at all to three decimal places for the depreciation rate scenarios considered. The R\&D GFCF/ GDP ratio is similarly insensitive, but does increase by 0.001 (one-tenth of a percentage point) when the land and buildings depreciation rate is reduced to 0.5 per cent. Key economic ratios (the last two columns of Table 11) are also insensitive. There is only a change to the third decimal place in the ratio of gross saving to gross national domestic income ratio, which rises by onetenth of a percentage point, again for a 1 percentage point reduction in the land and buildings depreciation rate to 0.5 per cent.

\section{Software estimates}

There are no changes in the key economic ratios or R\&D intensity indicators to three decimal places. The effects of changing the software deduction assumption are therefore minimal across the three key areas of the satellite account on which the sensitivity analysis focuses.

Performance, funding and ownership of R\&D

The R\&D intensity indicators and key economic ratios are also unchanged to three decimal places with respect to the assumed funding-ownership shares. This gives some justification to the original assumptions used in preliminary analysis since both the GDP and NDP estimates are robust, while the effects on the GSA were also small.

\section{Growth accounting}

Growth accounting is a technique used to attribute changes in the volume of output to changes in the volume of inputs - labour (quality-adjusted), non-R\&D capital and R\&D capital - based on the assumption that contributions of each input are proportional to their share in national income.

The benchmark results of Galindo- 
Table 9

\section{Sensitivity of GDP and NDP to the software deduction assumption, 2004}

f million, current prices

\begin{tabular}{rrrrrr}
\hline $\begin{array}{r}\text { Software } \\
\text { deduction (\%) }\end{array}$ & $\begin{array}{r}\text { Gross domestic } \\
\text { product (GDP) }\end{array}$ & $\begin{array}{r}\text { \% change from } \\
\text { the benchmark } \\
\text { analysis }\end{array}$ & $\begin{array}{r}\text { Net domestic } \\
\text { product (NDP) }\end{array}$ & $\begin{array}{r}\% \text { change from } \\
\text { the benchmark } \\
\text { analysis }\end{array}$ \\
\hline \multicolumn{2}{r}{ Software deduction (removing double counting) } \\
40 & $1,190,820$ & 0.01 & $1,048,047$ & 0.01 \\
Original & 10 & $1,190,695$ & & $1,047,990$ & -0.01 \\
& 60 & $1,190,382$ & -0.01 & $1,047,933$ & \\
\hline
\end{tabular}

Source: Office for National Statistics

Table 10

Sensitivity of GDP and NDP to funding share assumptions, 2004

£ million, current prices

\begin{tabular}{|c|c|c|c|c|c|}
\hline & Funding share (\%) & $\begin{array}{r}\text { Gross domestic } \\
\text { product (GDP) }\end{array}$ & $\begin{array}{r}\% \text { change from } \\
\text { the benchmark } \\
\text { analysis }\end{array}$ & $\begin{array}{l}\text { Net domestic } \\
\text { product (NDP) }\end{array}$ & $\begin{array}{r}\% \text { change from } \\
\text { the benchmark } \\
\text { analysis }\end{array}$ \\
\hline \multicolumn{6}{|c|}{ R\&D funded and owned by general government, performed by business enterprise } \\
\hline & 40 & $1,190,462$ & -0.01 & $1,047,720$ & -0.01 \\
\hline \multirow[t]{2}{*}{ Original } & 50 & $1,190,695$ & & $1,047,990$ & \\
\hline & 60 & $1,190,788$ & 0.01 & $1,048,098$ & 0.01 \\
\hline \multicolumn{6}{|c|}{ R\&D owned and funded by general government, performed by NPISH } \\
\hline & 5 & $1,190,668$ & -0.002 & $1,047,990$ & Unchanged \\
\hline \multirow[t]{2}{*}{ Original } & 10 & $1,190,695$ & & $1,047,990$ & \\
\hline & 15 & $1,190,722$ & 0.002 & $1,047,990$ & Unchanged \\
\hline \multicolumn{6}{|c|}{ R\&D owned and funded by the Rest of the World, performed by business enterprise } \\
\hline & 85 & $1,190,695$ & Unchanged & $1,047,841$ & -0.01 \\
\hline \multirow[t]{2}{*}{ Original } & 90 & $1,190,695$ & & $1,047,990$ & \\
\hline & 95 & $1,190,695$ & Unchanged & $1,048,139$ & 0.01 \\
\hline \multicolumn{6}{|c|}{ R\&D owned and funded by the Rest of the World, performed by general government } \\
\hline & 85 & $1,190,697$ & 0.0002 & $1,047,990$ & Unchanged \\
\hline \multirow[t]{2}{*}{ Original } & 90 & $1,190,695$ & & $1,047,990$ & \\
\hline & 95 & $1,190,692$ & -0.0003 & $1,047,990$ & Unchanged \\
\hline \multicolumn{6}{|c|}{ R\&D owned and funded by the Rest of the World, performed by NPISH } \\
\hline & 85 & $1,190,704$ & 0.0008 & $1,047,990$ & Unchanged \\
\hline \multirow[t]{2}{*}{ Original } & 90 & $1,190,695$ & & $1,047,990$ & \\
\hline & 95 & $1,190,686$ & -0.0008 & $1,047,990$ & Unchanged \\
\hline
\end{tabular}

Source: Office for National Statistics

Rueda (2007) suggest that, over the 1997 to 2004 period, R\&D made only a small contribution of 0.05 per cent to observed GVA growth of 2.8 per cent. By comparison, the contributions of non-R\&D capital and quality-adjusted labour were 1.45 and 0.8 per cent, respectively. The inclusion of R\&D therefore had little impact on the unexplained Solow residual, reducing its value from $0.55(2.8-1.45-0.8)$ per cent to 0.50 per cent via its 0.05 per cent contribution. An interesting question is whether this conclusion is sensitive to changes in key assumptions. This question is addressed in this section using the same scenarios, and the same 1997 to 2004 period used by Galindo-Rueda (2007).

\section{Depreciation rates}

The results for the four depreciation rates are given in Table 12. GVA growth sometimes changes slightly, but the contribution of R\&D capital to growth (and thus the reduction in the Solow residual) remains in the range 0.04 to 0.06 per cent. The role of $\mathrm{R} \& \mathrm{D}$ in explaining growth therefore remains rather small, and similar to the benchmark value of 0.05 per cent found by Galindo-Rueda (2007). This result is also consistent with earlier work by Edworthy and Wallis (2007), though users should note that this growthaccounting exercise captures only the direct contribution from 'owned' R\&D knowledge. The limited contribution of $\mathrm{R} \& \mathrm{D}$ to growth is the result of the low income share of R\&D accumulation remaining relatively constant with respect to changes in depreciation rates.

\section{Software and funding-ownership assumptions}

Both GVA and the contributions to growth of R\&D capital are unaffected to two decimal places by changes in the assumed shares of R\&D funded and owned by a given sector (but performed by a different sector) or the software deduction assumption. Further, for all these assumptions, this result is robust to the use of more extreme scenarios. ${ }^{5}$

\section{Conclusion}

This article has built upon previous work in Economic \& Labour Market Review, treating expenditure on research and development as investment in an intangible scientific asset. The sensitivity of the impacts of R\&D capitalisation previously quantified have been investigated via a sensitivity analysis on the key assumptions.

Taking 2004 as the reference year, the sensitivity of goods and services account impacts, GDP and NDP estimates, R\&D intensity indicators and key economic ratios have been examined. These results are rather robust to changes in key assumptions, with only goods and services account impacts showing significant sensitivity vis-à-vis the depreciation rates of $R \& D$ capital in the government and NPISH sectors.

In addition, growth-accounting results show a small but robust contribution of $\mathrm{R} \& \mathrm{D}$ to growth in recent years, consistent with previous work.

A key finding is that uncertainty regarding the correct depreciation rates in the government and NPISH sectors is important for R\&D capitalisation, but only at a relatively disaggregated - supply and demand - level.

\section{Notes}

1 The sensitivity analysis is carried out holding all other variables at their values in the benchmark analysis of Galindo-Rueda (2007).

2 This table is based on 'Methods for obtaining R\&D service lives', prepared for the OECD Task Force on R\&D and other Intellectual Property Products, 24-25 April 2008.

3 It is worth noting that Edworthy and Wallis (2007) have estimated the UK business sector $\mathrm{R} \& \mathrm{D}$ depreciation rate at 50 per cent. Results here are robust to the use of a 50 per cent depreciation rate. The GSA, GDP estimates and the R\&D intensity indicators and key economic ratios are left unchanged. The NDP estimate does change, but the impact is relatively small; NDP is only 0.07 per cent below the original estimate for a 20 per cent depreciation rate.

4 To produce relatively large changes in the total demand impact of around 4 per cent, a 25 percentage point change is required.

5 For example, using software deductions of 25 and 75 per cent does not change this conclusion. 
Table 11

Sensitivity of R\&D intensity indicators and key economic ratios to depreciation rates, 2004

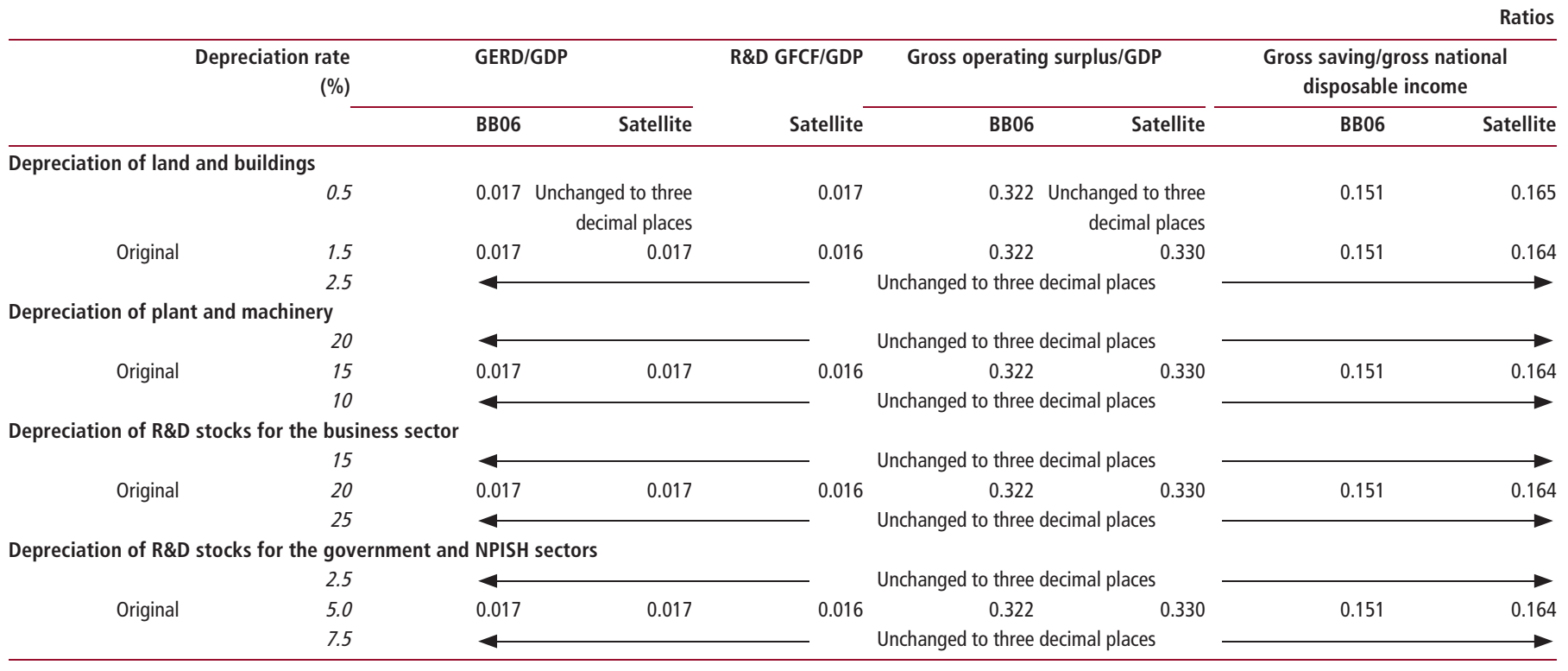

Source: Office for National Statistics

Table 12

Sensitivity of the impact of R\&D stock accumulation on economic growth to depreciation rates, 1997 to 2004

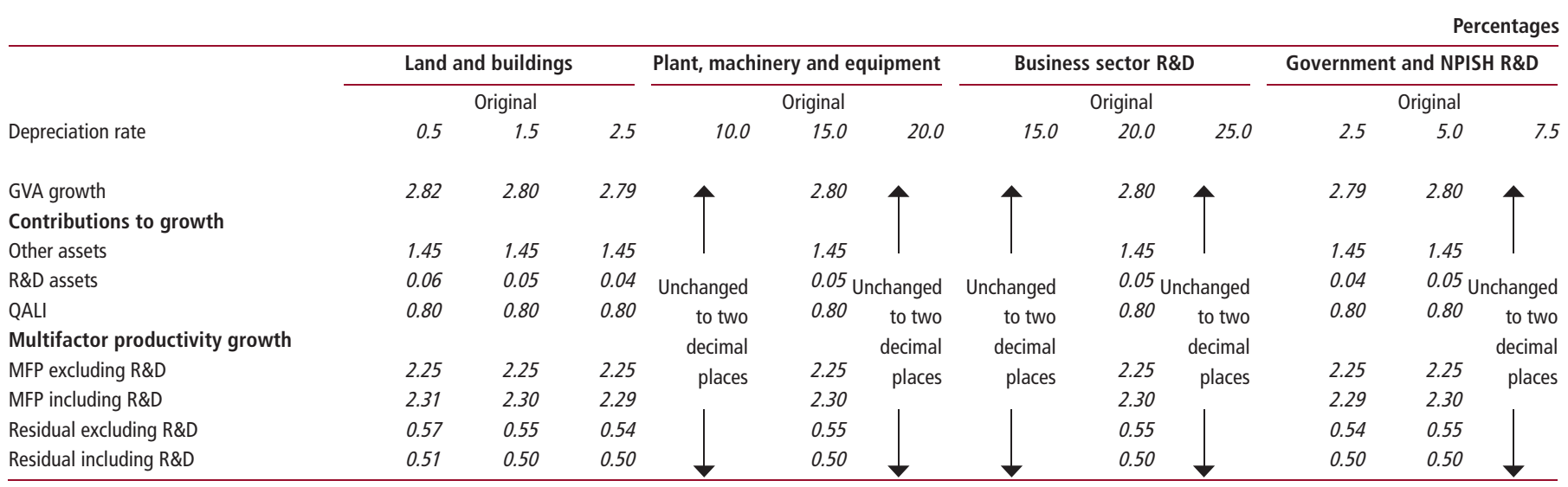

Note:

Source: Authors' calculations on a number of ONS sources

GVA excludes dwellings.

\section{ACKNOWLEGEMENTS}

The Office for National Statistics would like to thank Professor Barbara Fraumeni of the Muskie School of Public Service, University of Southern Maine, United States, for helpful comments.

\section{CONTACT}

(《)elmr@ons.gsi.gov.uk

\section{REFERENCES}

Edworthy E and Wallis G (2007) 'Treating research and development as a capital asset', Economic \& Labour Market Review 1(2), pp 16-25.

Galindo-Rueda F (2007) 'Developing an R\&D satellite account for the UK: A preliminary analysis', Economic \& Labour Market Review 1(12), pp 18-29.
Organisation for Economic Co-operation and Development (2002) Frascati Manual: Proposed standard practice for surveys on research and development, OECD Paris.

Organisation for Economic Co-operation and Development (2008) 'Methods for obtaining $R \& D$ service lives', prepared for the OECD Task Force on R\&D and other intellectual property products (unpublished), 24-25 April 2008.

Schankerman M and Pakes A (1986)

'Estimates of the value patent rights in European countries during the post-1950 period', The Economic Journal, Vol. 96, pp 1052-76. 